\title{
STATUT I REGULAMIN PAPIESKIEGO KOLEGIUM POLSKIEGO W RZYMIE Z 2002 R.
}

Treść: Wstęp. - 1. Zmiana i zatwierdzenie nowego Statutu oraz Regulaminu. 2. Zadania Kolegium. - 3. Zasady funkcjonowania i personel. - 4. Prawa i obowiązki księży studentów. - Zakończenie.

\section{Wstęp}

Papieskie Kolegium Polskie w Rzymie zostało utworzone w 1866 r. W tym samym roku nadano mu Regulamin ${ }^{1}$. Celem istnienia tej instytucji było przygotowywanie kandydatów do przyjęcia święceń kapłańskich i do podejmowania pracy na obszarach zamieszkałych przez ludność narodowości polskiej, znajdujących się wówczas pod zabora$\mathrm{mi}^{2}$. Przez prawie sto lat zasadniczo nie zmieniono tych uregulowań. Dopiero w końcu 1960 r. Święta Kongregacja Seminariów i Studiów Uniwersyteckich zatwierdziła nowy Statut i Regulamin, na mocy których Kolegium nadano kościelną osobowość prawną ${ }^{3}$.

W drugiej połowie XX w. do Papieskiego Kolegium Polskiego przyjmowano wyłącznie księży z Polski, których biskupi kierowali na studia specjalistyczne w papieskich uczelniach rzymskich. Wcześniej

${ }^{1}$ Por. Regolamento del Pontificio Collegio Polacco. Istituto in Roma, Roma 1866. Archiwum Papieskiego Kolegium Polskiego w Rzymie (skrót: APKP), sygn. Archiwum I (skrót: I) 25.1 .

2 M. Stęrień, Regulamin Papieskiego Kolegium Polskiego w Rzymie z 1866 r. (cel ustanowienia instytucji, zasady funkcjonowania, personel), Prawo Kanoniczne 54(2011), nr 1-2, s. 323.

${ }^{3}$ M. StęPIEŃ, Statut i Regulamin Papieskiego Kolegium Polskiego w Rzymie z 1960 roku, Perspectiva 20(2012), nr 1, s. 157-158, 163. 
studiowali tam alumni przygotowujący się do przyjęcia święceń kapłańskich ${ }^{4}$.

Niniejszy artykuł jest próbą przedstawienia aktualnie obowiązującego Statutu i Regulaminu Papieskiego Kolegium Polskiego. Opracowanie to wieńczy cykl publikacji autora, mający na celu opisanie prawno-organizacyjnego systemu funkcjonowania tej instytucji od momentu jej utworzenia.

\section{Zmiana i zatwierdzenie nowego Statutu oraz Regulaminu}

Kongregacja do spraw Wychowania Katolickiego, pismem z dnia 3 stycznia 1972 r. (Prot. N. 4/72/7), zwróciła się do rektorów papieskich seminariów, kolegiów i konwiktów kościelnych, by do czerwca tego samego roku przygotowali projekt statutów i regulaminów tych instytucji. W dokumentach należało uwzględnić postanowienia Soboru Watykańskiego II i „Ratio fundamentalis”. Nie wszystkie zainteresowane instytucje wywiązały się z tego zadania, gdyż w piśmie z 21 lipca tego samego roku, Kongregacja przypomniała rektorom o potrzebie sporządzenia projektów ${ }^{5}$. W grudniu 1972 r. ks. Bolesław Wyszyński, rektor Kolegium przesłał do Stolicy Apostolskiej projekt statutu i regulaminu, jednocześnie usprawiedliwiając opóźnienie w przygotowaniu dokumentów przyczynami od niego niezależnymi ${ }^{6}$. Projekt statutu był bardzo krótki, spisany w języku włoskim mieścił się na jednej stronie maszynopisu. Nie było w nim podziału na artykuły ani punkty, a jego forma nie spełniała podstawowych wymogów prawnych przyjętych dla tego typu dokumentów. W projekcie zapisano, że Kolegium zostało ufundowane przez papieża Piusa IX w 1866 r. w celu kształcenia młodzieży polskiej przygotowującej się do kapłaństwa. Dalej stwierdzono, że po drugiej wojnie światowej Episkopat Polski zadecydował, że do Rzymu będą wysyłani tylko kapłani - w ten sposób Kolegium stało się

4 Tamże, s. 163.

5 Pismo. Sacra Congregatio pro Institutione Catholica ai Rettori dei Pontifici Seminari, Collegi e Convitti Ecclesiastici. Roma, 21-07-1972 (Prot. N. 4/72/42). APKP, sygn. Archiwum III (skrót: III) 28.2.

${ }^{6}$ List. Ks. B. Wyszyński do Prefekta Kongregacji do spraw Wychowania Katolickiego. Roma, 08-12-1972 (uwierzytelniona kopia). APKP, sygn. III 28.2. 
konwiktem księży7. Według przedstawionego projektu, Kongregacja do spraw Wychowania Katolickiego miała mianować rektora Kolegium, przy czym propozycję kandydata wysuwałby Episkopat Polski. Projekt regulaminu był natomiast podzielony na jedenaście punktów spisanych na niespełna dwóch stronach maszynopisu. W tym przypadku także ten dokument nie spełniał podstawowych wymogów prawnych ${ }^{8}$. W efekcie Kongregacja nie zatwierdziła wówczas ani statutu, ani regulaminu Papieskiego Kolegium Polskiego.

W kolejnych latach Stolica Apostolska jeszcze dwukrotnie kierowała pisma do rektorów, prosząc o podjęcie prac nad zmianą statutów i regulaminów oraz przekazując pomocne materiały9. Jednak, jak wynika ze sprawozdań z działalności polskiego Kolegium przedkładanych Kongregacji każdego roku, działań tych nie zdołano uwieńczyć powodzeniem, więc w rezultacie Statut i Regulamin Kolegium z 1960 r. obowiązywały niezmiennie ${ }^{10}$.

W związku z przygotowaniami do obchodów Wielkiego Jubileuszu Roku 2000 w listopadzie 1998 r., Kongregacja do spraw Wychowania

${ }^{7}$ Projekty Statutu i Regulaminu (wysłane do Kongregacji bez daty i podpisu). APKP, sygn. III 28.2. Przytoczone stwierdzenie rektora Wyszyńskiego nie jest prawdziwe, gdyż, jak wynika z list alumnów, klerycy przygotowujący się do kapłaństwa po raz ostatni zamieszkiwali w Kolegium w roku akademickim 1962-1963. Por. Listy i wykazy alumnów kolegium. 23-11-1953, 20-10-1954, 30-10-1959, 03-11-1960, 2303-1962, 08-09-1963, 29-01-1964, 17-05-1965. APKP, sygn. III 39.

${ }^{8}$ Projekty Statutu i Regulaminu (wysłane do Kongregacji bez daty i podpisu). APKP, sygn. III 28.2. Por. List. Wyszyński do Prefekta Kongregacji do spraw Wychowania Katolickiego. Roma, 08-12-1972. (uwierzytelniona kopia) APKP, sygn. III 28.2. W projekcie Statutu zapisano, że Papieskie Kolegium Polskie znajduje się pod ojcowskim protektoratem Prymasa Polski, któremu rektor każdego roku zobowiązany jest przedstawić sprawozdanie z działalności Kolegium.

9 Pisma Kongregacji z 1 marca 1975 r. i 30 września 1980 r., w których zamieszczono wskazania dotyczące redagowania statutów i regulaminów. Por. Pismo. Congregatio de Institutione Catholica ai Rettori dei Pontifici Seminari, Collegi e Convitti Ecclesiastici. Roma, 04-11-1998. Prot. N. 1047/98/2. APKP, sygn. III 44, s. 3-5.

${ }^{10}$ Por. Relazione del Pontificio Collegio Polacco per l'anno 1985-1986 (uwierzytelniona kopia). Sprawozdania przekazywane do Kongregacji w latach: 1986-1987, 1987-1988, 1988-1989, 1989-1990, 1990-1991, 1991-1992, 1992-1993, 1993-1994, 1995-1996, 1996-1997 (uwierzytelnione kopie), APKP, sygn. III 20, 44. 
Katolickiego skierowała obszerne pismo do rektorów papieskich seminariów, kolegiów i konwiktów, w którym prosiła o zintensyfikowanie prac nad problematyką związaną z działalnością tych instytucji ${ }^{11}$. Szczególną uwagę zwrócono na potrzebę stworzenia nowego systemu prawno-organizacyjnego tych instytucji, który określono jako zasadniczy punkt w linii programowej przygotowań do Wielkiego Jubileuszu Roku 2000, z czym wiązało się przygotowanie zmian statutów i regulaminów ${ }^{12}$. Kongregacja zaproponowała podjęcie prac w czterech zasadniczych kierunkach: życiu duchowym, dyscyplinie, studiach i praktycznej formacji pastoralnej ${ }^{13}$. W załączniku do pisma umieszczono szczegółowe wytyczne dotyczące treści nowych statutów i regulaminów. Polecono, by statuty zawierały dwanaście następujących punktów: „Preambuła historyczna”, „Utworzenie i założenie”, „Natura i cel”, „Kształt prawny”, „Zarząd”, „Studenci”, „Życie wspólnotowe”, „Relacje kolegium w stosunku do podmiotów «ad extra»”, „Komisja Nadzorcza (Rada Administracyjna)”, „Administracja ekonomiczna”, „Wygaśnięcie”, „Przepisy końcowe”14. Regulaminy kolegiów, w których zamieszkiwaliby wyłącznie księża, miały być podzielone na następujące części: „Wstęp”, „Zarząd”, „Studenci”, „Główne wskazania formacyjne”, „Wspólnota”, „Dobra doczesne i administracja”15. Kongregacja do spraw Wychowania Katolickiego, pismem z dnia 29 stycz-

${ }^{11}$ Pismo. Congregatio de Institutione Catholica ai Rettori dei Pontifici Seminari, Collegi e Convitti Ecclesiastici. Roma, 04-11-1998. Prot. N. 1047/98/2. APKP, sygn. III 44, s. 1-12.

12 Tamże, s. 3.

${ }^{13}$ Tamże.

${ }^{14} \mathrm{~W}$ oryginale punkty te brzmią następująco: "Preambolo storico, Costituzione, Natura e fine, Configurazione giuridica, Governo, Alunni, Vita comunitaria, Relazione del Collegio «ad extra», Commissione di Vigilanza (Consiglio di Amministrazione), Amministrazione economica, Estinzione, Clausula finale". Pismo. Congregatio de Institutione Catholica ai Rettori dei Pontifici Seminari, Collegi e Convitti Ecclesiastici. Roma, 04-11-1998. Prot. N. 1047/98/2. APKP, sygn. III 44, s. 13-15.

${ }^{15} \mathrm{~W}$ oryginale części te są zatytułowane następująco: "Introduzione, Direzione, Alunni Principali dimensioni formative, Comunità del Seminario, Beni Temporali, amministrazione". Pismo. Congregatio de Institutione Catholica ai Rettori dei Pontifici Seminari, Collegi e Convitti Ecclesiastici. Roma, 04-11-1998. Prot. N. 1047/98/2. APKP, sygn. III 44, s. 22-25. 
nia 2001 r., zwróciła uwagę rektorowi Papieskiego Kolegium Polskiego na to, by pilnie zredagował projekt statutu i regulaminu, gdyż Kolegium przez niego zarządzane znalazło się w niewielkiej grupie tych instytucji, które nie wypełniły tego obowiązku we właściwym czasie ${ }^{16}$.

Aktualnie obowiązujące: Statut i Regulamin Papieskiego Kolegium Polskiego w Rzymie z dnia 28 czerwca 2002 r., zostały zaaprobowane przez Kongregację do spraw Wychowania Katolickiego ${ }^{17}$ dekretami z 4 lipca 2002 r. (Prot. N. 664/2002/5, 664/2005/6) ${ }^{18}$. Statut został podzielony na trzynaście następujących artykułów: „Preambuła historyczna”, „Natura i cel”, „Sytuacja prawna i siedziba”, „Kierownictwo”, „Studenci”, „Kompetencje Konferencji Episkopatu Polski”, „Administracja”, „Komisja Nadzorcza”, „Majątek nieruchomy”, „Fundusze na działalność”, „Wygaśnięcie”, „Przepisy uzupełniające”, „Ważność Statutu” ${ }^{19}$. Struktura Statutu Kolegium w zasa-

${ }^{16}$ Pismo. Congregatio de Institutione Catholica al Rettore del Pontificio Collegio Polacco. Roma, 29-01-2001. Prot. N. 110/2001. APKP, sygn. III 44, s. 1-3.

${ }^{17}$ W Statucie i Regulaminie Papieskiego Kolegium Polskiego z 2002 r. używana jest nazwa „Kongregacja Nauczania Katolickiego”.

${ }^{18}$ Oto treść dekretów: "CONGREGATIO DE INSTITUTIONE CATHOLICA (DE SEMINARIIS ATQUE STUDIORUM INSTITUTIS) STATUTA Pontificii Collegii Polonici in Urbe vigentis libenter rata habet atque approbat, eademque ab omnibus quorum interest rite servari iubet; contrariis quibuslibet minime obstantibus". Dekret Kongregacji do spraw Wychowania Katolickiego aprobujący Statut Papieskiego Kolegium Polskiego w Rzymie. Rzym, 04-07-2002. Prot. N. 664/2002/5. APKP, sygn. III 28.5. CONGREGATIO DE INSTITUTIONE CATHOLICA (DE SEMINARIIS ATQUE STUDIORUM INSTITUTIS) NORMAS VITAE Pontificii Collegii Polonici in Urbe vigentis libenter ratas habet atque approbat, easdemque ab omnibus quorum interest rite servari iubet; contrariis quibuslibet minime obstantibus". Dekret Kongregacji do spraw Wychowania Katolickiego aprobujący Regulamin Papieskiego Kolegium Polskiego w Rzymie. Rzym, 04-07-2002. Prot. N. 664/2002/6. APKP, sygn. III 28.5 .

${ }^{19}$ Papieskie Kolegium Polskie w Rzymie. Statut z Regulaminem. Warszawa, 2806-2002. APKP, sygn. III 28.5, s. 1-5. Prawie identyczny podział i treść artykułów znajduje się w Statucie Papieskiego Seminarium Lombardo. Por. Pontificio Seminario Lombardo dei santi Ambrogio e Carlo in Roma. Satuto Lineamenti di Vita e Regolamento, Roma 1991. APKP, sygn. III 44, s. 13-17. Identyczny podział i prawie identyczne tytuły poszczególnych artykułów znajdują się w Statucie Papieskiego Kościelnego Instytutu Polskiego w Rzymie z 30 stycznia 2004 r., który został zaaprobowany przez 
dzie realizowała wskazania Kongregacji do spraw Wychowania Katolickiego z $1998 \mathrm{r}$.

Regulamin Kolegium natomiast podzielono na czternaście następujących punktów: „Wprowadzenie”, „Normy ogólne”, „Formacja duchowa”, „Formacja intelektualna”, „Życie wspólnotowe”, „Działalność duszpasterska”, „Inne normy”. Kolejne punkty (od ósmego do czternastego) nazwano „Zasadami życia” i zatytułowano kolejno: „Natura i cel Papieskiego Kolegium Polskiego”, „Okazja do stałej formacji”, „Skierowanie przez biskupa”, „W służbie Kościołowi”, „Specjalizacja naukowa”, „Wspólnota kapłańska”, „Kościół Rzymu i miasto Rzym" ${ }^{20}$. We wprowadzeniu stwierdzono, że zawarte w nim normy „winny być rozważone i przyjęte w duchu wolności oraz odpowiedzialności za wspólną drogę, tak by pomogły każdemu do osiągnięcia dojrzałości w kapłańskiej posłudze dla Kościoła”"21. W wielu miejscach Regulaminu odwołano się do konkretnych przepisów Statutu, a w punkcie drugim, w „Normach ogólnych”, prawie dosłownie powtórzono liczne zasady ze Statutu² ${ }^{22}$.

\section{Zadania Kolegium}

W pierwszym artykule Statutu Kolegium zawarta jest nota historyczna mówiąca o jego początkach, oficjalnym erygowaniu i celu powołania. Historia Papieskiego Kolegium Polskiego sięga instytucji utworzonej dla Polaków przez św. Filipa Nereusza w 1582 r. Po kilku latach istnienia zlikwidowano ją, a w XVII w. nie powiodła się próba utrzymania wspólnego Kolegium dla Polaków i Szwedów. W efekcie Papieskie Kolegium Polskie utworzono dopiero w drugiej połowie XIX w. w celu formacji kandydatów do kapłaństwa. Gościło ono także

Kongregację do spraw Wychowania Katolickiego dekretem z dnia 2 marca 2004 r. W stosunku do Statutu Kolegium odnajdujemy dwie różnice w tytułach artykułów: 4. Zarządzanie, 8. - Rada Nadzorcza. Papieski Kościelny Instytut Polski w Rzymie. Statut. Warszawa, 30-01-2004. APKP, sygn. III 28.6.

${ }^{20}$ Por. pkt 1-14, Papieskie Kolegium Polskie w Rzymie. Statut z Regulaminem. Warszawa, 28-06-2002. APKP, sygn. III 28.5, s. 6-14.

${ }^{21}$ Tamże, s. 6.

${ }^{22}$ Por. tamże, s. 6-7. 
kapłanów, którzy studiowali w różnych rzymskich uczelniach kościelnych $^{23}$.

Obecnie Papieskie Kolegium Polskie określa się jako rzymską instytucję kościelną, która, „pozostając w szczególnej zależności od Stolicy Apostolskiej, jest poddana władzy i nadzorowi Konferencji Episkopatu Polski"24. W poprzednim Statucie z 1960 r. użyto formuły, że instytucja ta pozostawała pod zwierzchnictwem papieża, a w jego imieniu władzę administracyjną sprawowała Kongregacja Seminariów i Studiów Uniwersyteckich. Dokument ten przewidywał wówczas funkcję kardynała protektora ${ }^{25}$. Natomiast, na mocy obowiązującego Statutu, uprawnienia nadzorcze nad Kolegium otrzymała Konferencja Episkopatu Polski, nie wspomina się już o funkcji kardynała protektora $^{26}$.

Do Kolegium przyjmowani są polscy kapłani, odpowiednio uzdolnieni, którzy po ukończeniu seminariów duchownych zostali skierowani przez swych biskupów do odbycia specjalistycznych studiów na uczelniach kościelnych w Rzymie ${ }^{27}$. Podobnie brzmią dwa pierwsze artykuły Statutu Seminarium Lombardo z $1991 \mathrm{r}^{28}$, a wspomniany już Statut Papieskiego Kościelnego Instytutu Polskiego z 2004 r. zezwala dodatkowo na przyjmowanie księży zakonnych ${ }^{29}$.

${ }^{23}$ Art. 1, tamże, s. 2.

${ }^{24}$ Art. 2, tamże.

${ }^{25}$ Pkt 1, 3-4. Statuta Pontificii Collegii Polonorum in Urbe (uwierzytelniony odpis). Rzym, 12-12-1960. Ad N. 3217/60/P. APKP, sygn. III 28.2, s. 1. Por. M. StĘPIEŃ, Statut i Regulamin Papieskiego Kolegium Polskiego w Rzymie z 1960 roku, Perspectiva 20(2012), nr 1, s. 158-159.

${ }^{26}$ Art. 6, Papieskie Kolegium Polskie w Rzymie. Statut z Regulaminem. Warszawa, 28-06-2002. APKP, sygn. III 28.5, s. 3. Por. M. STęPIEŃ, Statut i Regulamin Papieskiego Kolegium Polskiego w Rzymie z 1960 roku, Perspectiva 20(2012), nr 1, s. 160.

${ }^{27}$ Art. 2, Papieskie Kolegium Polskie w Rzymie. Statut z Regulaminem. Warszawa, 28-06-2002. APKP, sygn. III 28.5, s. 2.

${ }^{28}$ Por. Pontificio Seminario Lombardo dei santi Ambrogio e Carlo in Roma. Satuto Lineamenti di Vita e Regolamento, Roma 1991. APKP, sygn. III 44, s. 13-14.

${ }^{29}$ Art. 2, Papieski Kościelny Instytut Polski w Rzymie. Statut. Warszawa, 30-012004. APKP, sygn. III 28.6. 
Poprzedni Statut Kolegium z 1960 r. stwierdzał, że zadaniem tej instytucji było przyjmowanie kandydatów z polskich diecezji w celu ich kształcenia i przygotowywania do przyjęcia święceń kapłańskich ${ }^{30}$. Obecnie Papieskie Kolegium Polskie jest instytucją kościelną, posiadającą osobowość prawną w świetle prawa kanonicznego, a w systemie prawa włoskiego osobowość prawną uznaną przez Republikę Włoską, do której są przyjmowani kapłani z Polski podejmujący studia w Rzymie ${ }^{31}$.

\section{Zasady funkcjonowania i personel}

W Statucie Kolegium z 2001 r. podkreśla się, że wskazania dotyczące życia i zarządu tej instytucji są określone przez Konferencję Episkopatu Polski, z uwzględnieniem zarządzeń Kongregacji Nauczania Katolickiego odnoszących się do rzymskich kolegiów kościelnych. Dalej wymienia się kompetencje Konferencji Episkopatu Polski odnoszące się do Kolegium:

„- dokonywanie ewentualnych zmian w Statucie, po uzyskaniu nihil obstat ze strony Stolicy Apostolskiej; - aprobata Regulaminu Kolegium i przedstawienie do aprobaty Kongregacji Nauczania Katolickiego; - prezentacja kandydata na Rektora; - nominacja członków Komisji Nadzorczej; - nominacja Kierownika Duchownego; - nominacja Spowiedników zwyczajnych i nadzwyczajnych; - nominacja Wicerektora-Ekonoma; - kontrola sprawozdania formacyjno-ekonomicznego przedkładanego co roku przez Rektora i doroczna aprobata do 31 marca rozliczenia finansowego za rok poprzedni" 32 .

${ }^{30}$ Por. pkt 2. Statuta Pontificii Collegii Polonorum in Urbe (uwierzytelniony odpis). Rzym, 12-12-1960. Ad N. 3217/60/P. APKP, sygn. III 28.2, s. 1; por. M. StĘPIEŃ, Statut i Regulamin Papieskiego Kolegium Polskiego w Rzymie z 1960 roku, Perspectiva 20(2012), nr 1, s. 157-158.

${ }^{31}$ Art. 3, Papieskie Kolegium Polskie w Rzymie. Statut z Regulaminem. Warszawa, 28-06-2002. APKP, sygn. III 28.5, s. 2. Dokument stwierdzający posiadanie osobowości prawnej przez Papieskie Kolegium Polskie w systemie prawa włoskiego został wystawiony przez Ministra Spraw Wewnętrznych Republiki Włoskiej dnia 20 lipca 1987 r. Por. Pismo. Il Ministro dell'Interno. Roma, 20-07-1987. APKP, sygn. III 16.

${ }^{32}$ Art. 6, Papieskie Kolegium Polskie w Rzymie. Statut z Regulaminem. Warszawa, 28-06-2002. APKP, sygn. III 28.5, s. 3. Kompetencje Konferencji Episkopatu Polski 
Zgodnie ze Statutem, Konferencja Episkopatu Polski w stosunkach z Papieskim Kolegium Polskim jest reprezentowana przez jej przewodniczącego ${ }^{33}$. Rok administracyjny w Kolegium zaczyna się w dniu 1 października, a kończy 30 września każdego roku. Rozliczenie finansowe przygotowuje rektor do 30 listopada i przedstawia do aprobaty Kongregacji Nauczania Katolickiego i Konferencji Episkopatu Polski ${ }^{34}$.

Komisja Nadzorcza ma za zadanie wspomaganie rektora w wykonywaniu jego funkcji wychowawczych i administracyjnych. W skład jej wchodzą czterej polscy kapłani rezydujący w Rzymie, mianowani przez Konferencję Episkopatu Polski na okres pięciu lat, z możliwością ponowienia nominacji. Komisja Nadzorcza spełnia funkcje doradcze, czuwając nad przestrzeganiem zarządzeń Stolicy Apostolskiej i Konferencji Episkopatu Polski ${ }^{35}$. Statut Papieskiego Seminarium Lombardo z 1991 r. podobnie regulował działalność Komisji Nadzorczej, z tą jednak różnicą, że w skład tego gremium wchodziło nie czterech a trzech kapłanów rezydujących w Rzymie ${ }^{36}$. Natomiast Statut Kolegium z 1960 r. przewidywał funkcję dwóch deputatów, z których jeden zajmował się sprawami administracyjnymi, a drugi zasadami zachowania dyscypliny w Kolegium ${ }^{37}$. W obecnie obowiązującym Statu-

w Statucie Papieskiego Kościelnego Instytutu Polskiego zostały rozszerzone o następujące trzy punkty: „decyzja o zaprzestaniu działalności Instytutu”; „ustalenie wysokości wynagrodzenia osób pracujących w Instytucie, rodzaju i wysokości innych świadczeń”; ,ustalenie wysokości rocznej opłaty uiszczanej przez kapłanów studentów za miejsce w domu". Art. 6, Papieski Kościelny Instytut Polski w Rzymie. Statut. Warszawa, 30-01-2004. APKP, sygn. III 28.6.

${ }^{33}$ Art. 6, Papieskie Kolegium Polskie w Rzymie. Statut z Regulaminem. Warszawa, 28-06-2002. APKP, sygn. III 28.5, s. 3.

${ }^{34}$ Art. 7, tamże, s. 4.

${ }^{35}$ Art. 8, tamże.

${ }^{36}$ Por. art. 5, Pontificio Seminario Lombardo dei santi Ambrogio e Carlo in Roma. Satuto Lineamenti di Vita e Regolamento, Roma 1991. APKP, sygn. III 44, s. 15-16. W Statucie Papieskiego Kościelnego Instytutu Polskiego różnica w art. 8 polega tylko na zmianie nazwy tego gremium na „Radą Nadzorczą”. Por. art. 8, Papieski Kościelny Instytut Polski w Rzymie. Statut. Warszawa, 30-01-2004. APKP, sygn. III 28.6.

${ }^{37} \mathrm{Pkt}$ 7. Statuta Pontificii Collegii Polonorum in Urbe (uwierzytelniony odpis). Rzym, 12-12-1960. Ad N. 3217/60/P. APKP, sygn. III 28.2, s. 2. Por. M. StĘPIEŃ, Sta- 
cie nie ma już funkcji deputatów, na ich miejsce utworzono czteroosobową Komisję Nadzorczą.

W wypadku wygaśnięcia lub zniesienia Kolegium do Konferencji Episkopatu Polski należy zadysponowanie jego majątkiem, po wcześniejszym uzyskaniu, „nihil obstat” od Stolicy Apostolskiej. W zakończeniu Statutu umieszczono zasadę ogólną, że w sprawach nieokreślonych w tym dokumencie należy kierować się normami prawa kanonicznego i prawa świeckiego włoskiego odnoszącymi się do instytucji kościelnych. Statut nie może być ani odwołany, ani zmieniony bez wyraźniej aprobaty Kongregacji Nauczania Katolickiego ${ }^{38}$. Zapisy artykułów od dziewiątego do trzynastego Statutu Papieskiego Kościelnego Instytutu Polskiego są identyczne, co świadczy o tym, iż przy jego tworzeniu korzystano z tekstu Statutu Papieskiego Kolegium Polskiego ${ }^{39}$.

Pełnomocnym, prawnym reprezentantem Kolegium jest rektor, który kieruje tą instytucją. Kandydaturę rektora (spośród kapłanów z polskich diecezji) przedstawia Konferencja Episkopatu Polski, a jego nominacji dokonuje Kongregacja Nauczania Katolickiego na okres sześciu lat, z możliwością jej ponowienia. Rektor zobowiązany jest troszczyć się o właściwy przebieg życia w Kolegium, zgodnie ze wskazaniami Stolicy Apostolskiej oraz Konferencji Episkopatu Polski $^{40}$.

tut i Regulamin Papieskiego Kolegium Polskiego w Rzymie z 1960 roku, Perspectiva 20(2012) nr 1, s. 159.

${ }^{38}$ Art. 11-13, Papieskie Kolegium Polskie w Rzymie. Statut z Regulaminem. Warszawa, 28-06-2002. APKP, sygn. III 28.5, s. 4-5.

${ }^{39}$ Por. art. 9-13, Papieski Kościelny Instytut Polski w Rzymie. Statut. Warszawa, 30-01-2004. APKP, sygn. III 28.6.

${ }^{40}$ Art. 3-4, Papieskie Kolegium Polskie w Rzymie. Statut z Regulaminem. Warszawa, 28-06-2002. APKP, sygn. III 28.5, s. 2-3. Treść art. 3 Statutu Papieskiego Kościelnego Instytutu Polskiego jest identyczna. Por. art. 3, Papieski Kościelny Instytut Polski w Rzymie. Statut. Warszawa, 30-01-2004. APKP, sygn. III 28.6. Jak się wydaje, kadencyjność funkcji rektora została wprowadzona przez Stolicę Apostolską do statutów papieskich kolegiów i seminariów na przełomie XX i XXI w. Por. Pontificio Seminario Lombardo dei santi Ambrogio e Carlo in Roma. Satuto Lineamenti di Vita e Regolamento, Roma 1991. APKP, sygn. III 44, s. 13-14. 
Konferencja Episkopatu Polski, zgodnie z potrzebami Kolegium, po konsultacji przeprowadzonej z rektorem, może mianować na trzyletnią kadencję wicerektora-ekonoma, którego zadaniem jest wspomaganie rektora i zastępowanie go w czasie nieobecności lub choroby. Statut przewiduje też funkcję kierownika duchownego, mianowanego na pięć lat. $\mathrm{W}$ miarę potrzeby mogą być też mianowani na okres trzech lat spowiednicy zwyczajni i nadzwyczajni. Zgodnie ze Statutem, Konferencja Episkopatu Polski posiada kompetencję mianowania na wszystkie wyżej wymienione funkcje, zawsze z możliwością ponowienia nominacji na następne kadencje ${ }^{41}$.

Rektor w każdym roku zobowiązany jest przedkładać Kongregacji Nauczania Katolickiego i Konferencji Episkopatu Polski sprawozdanie o stanie Kolegium, ze szczególnym uwzględnieniem procesu formacyjnego studentów i sytuacji finansowej oraz majątkowej ${ }^{42}$.

W sposób szczególny w Regulaminie podkreślono, że rektor odpowiada za kierowanie codziennym życiem Kolegium we wszystkich jego aspektach. Jego zadaniem jest „tworzenie klimatu braterskiego zaufania w relacjach z poszczególnymi księżmi studentami” i towarzyszenie księżom w ich studiach i posłudze kapłańskiej ${ }^{43}$. Do zadań rektora należy „coroczne poinformowanie Biskupa diecezjalnego o postępie w studiach i całej postawie jego kapłanów" "44. Chociaż nie określono tego precyzyjnie, to wydaje się, że obowiązek informowania biskupów diecezjalnych rektor wypełnia poprzez wystawienie, na zakończenie roku akademickiego, pisemnej opinii o każdym studencie zamieszkującym w Papieskim Kolegium Polskim. W omawianym dokumencie umieszczono generalną zasadę, że każdej polskiej diecezji

\footnotetext{
${ }^{41}$ Art. 4, Papieskie Kolegium Polskie w Rzymie. Statut z Regulaminem. Warszawa, 28-06-2002. APKP, sygn. III 28.5, s. 3.

${ }^{42}$ Art. 4, tamże. W treści art. 4 Statutu Papieskiego Kościelnego Instytutu Polskiego dodano zapis o prawie rektora i wicerektora-ekonoma do ,30-dniowego urlopu i wynagrodzenia ustalanego prze Konferencję Episkopatu Polski”: Art. 4, Papieski Kościelny Instytut Polski w Rzymie. Statut. Warszawa, 30-01-2004. APKP, sygn. III 28.6.

${ }^{43}$ Pkt 2.2, Papieskie Kolegium Polskie w Rzymie. Statut z Regulaminem. Warszawa, 28-06-2002. APKP, sygn. III 28.5, s. 6.

${ }^{44}$ Tamże.
} 
przysługuje prawo do dwóch miejsc dla studentów w Rzymie, czyli w Papieskim Kolegium Polskim lub w Papieskim Instytucie Polskim ${ }^{45}$.

\section{Prawa i obowiązki księży studentów}

Miejsce w Kolegium przyznaje studentowi przewodniczący Konferencji Episkopatu Polski na wniosek zainteresowanego biskupa, od którego kandydat wcześniej powinien otrzymać dekret zezwalający na podjęcie nauki w Rzymie. Księża, którzy zostali przyjęci do Kolegium, zobowiązani są zapoznać się ze Statutem i Regulaminem Kolegium i na piśmie, w obecności rektora, zobowiązać się, że dołożą starań, aby wypełnić postanowienia w nich zawarte ${ }^{46}$. Usunięcie studenta z Kolegium zastrzeżone jest przewodniczącemu Konferencji Episkopatu Polski, po uprzednim wysłuchaniu zainteresowanego biskupa diecezjalnego, rektora i Komisji Nadzorczej Kolegium. Każdy kapłan jest zobowiązany do natychmiastowego powrotu do swojej diecezji po zakończeniu studiów lub na wezwanie właściwego biskupa ${ }^{47}$.

W Regulaminie podkreślono znaczenie formacji duchowej księży studentów w ich życiu kapłańskim, a także potrzebę ciągłego rozwijania duchowości poprzez obowiązkowe koncelebrowanie Mszy św., recytowanie „Jutrzni” i „Nieszporów” oraz poprzez adorację Najświętszego Sakramentu i oddawanie się prywatnej modlitwie. Zachęca się studentów, aby regularnie przystępowali do sakramentu pokuty i uczestniczyli w innych wspólnotowych praktykach pobożności. W Kolegium przewidziano przynajmniej trzydniowe rekolekcje odbywające się raz w roku, w czasie Wielkiego Postu, oraz celebrowanie nabożeństw majowych, czerwcowych i październikowych. Oprócz tego, w każdym roku obchodzi się uroczystość św. Jana Kantego i błogosławionego papieża Piusa IX - założyciela Kolegium. Regulamin nakłada obowiązek odprawiania pięćdziesięciu Mszy św. „wieczystych" w roku, zgodnie z intencjami fundatorów, za co odpowiada rek-

\footnotetext{
${ }^{45}$ Pkt 2.7, tamże, s. 6-7.

${ }^{46}$ Art. 5, pkt 2.7, tamże, s. 3, 6-7.

${ }^{47}$ Pkt 2.7, tamże, s. 6-7.
} 
tor $^{48}$. W Statucie z 1960 r. określono, że rekolekcje powinny odbywać się na początku każdego roku akademickiego i trwać pięć pełnych dni, obowiązkiem alumnów było też przystępowanie do sakramentu pokuty co najmniej raz w tygodniu ${ }^{49}$.

Nie mniej ważną rolę spełnia też formacja intelektualna. W punkcie 4.1. Regulaminu wręcz stwierdzono, że „księża studenci powinni uważać naukę za swoją główną misję i istotne zadanie w służbie Kościołowi" ${ }^{50}$. Regulamin nakłada na studentów obowiązek przestrzegania norm uczelni, na które uczęszczają, a także odbywania studiów specjalistycznych, na które zostali skierowani. Student jest zobowiązany zdawać relację rektorowi i swojemu biskupowi z postępów w zdobywaniu wiedzy. Nie jest dopuszczalne, aby mógł samodzielnie, bez zgody swojego biskupa, dokonywać zmiany dyscypliny naukowej ${ }^{51}$.

W życiu wspólnotowym każdy student ma odnosić się do rektora i moderatorów z szacunkiem, otwartością i zaufaniem oraz przyjmować polecenia od przełożonych w duchu posłuszeństwa i zrozumienia. Wśród księży powinna panować atmosfera braterstwa i życzliwości, bez wszczynania konfliktów. Usilnie zaleca się, aby wszyscy kapłani unikali palenia tytoniu, szczególnie w miejscach publicznych, a w kwestiach dotyczących ubioru stosowali się do zarządzeń kardynała Wikariusza Miasta ${ }^{52}$. W Regulaminie zamieszczono wskazania dotyczące postępowania $\mathrm{w}$ różnych sytuacjach. Nakazano unikania „czynienia hałasu, zwłaszcza nocą i po obiedzie"53. Każdy student ma obowiązek troszczyć się o stan i wygląd własnego pokoju, skąd nie można samowolnie usuwać ani wstawiać innych mebli. Księża, któ-

${ }^{48}$ Pkt 3, tamże, s. 7-8.

${ }^{49} \mathrm{Pkt} 7$, 9. Statuta Pontificii Collegii Polonorum in Urbe (uwierzytelniony odpis). Rzym, 12-12-1960. Ad N. 3217/60/P. APKP, sygn. III 28.2, s. 3. Por. M. STĘPIEŃ, Prawa $i$ obowiązki alumnów w Statucie i Regulaminie Papieskiego Kolegium Polskiego w Rzymie z 1960 r. Prawo Kanoniczne 55(2012), nr 4, s. 177-178.

${ }^{50}$ Pkt 4.1, Papieskie Kolegium Polskie w Rzymie. Statut z Regulaminem. Warszawa, 28-06-2002. APKP, sygn. III 28.5, s. 8.

${ }^{51}$ Pkt 4,2, 4.4, tamże.

${ }^{52}$ Pkt 5.1-5.5, tamże, s. 8-9.

${ }^{53}$ Pkt 5.7, tamże, s. 9. 
rzy wyjeżdżają poza Rzym, powinni wcześniej powiadomić rektora o przewidywanym okresie nieobecności i pozostawić adres lub kontaktowy numer telefonu. Podkreślono, że koszty leczenia, lekarstw i polisy ubezpieczeniowej od leczenia w szpitalu, studenci muszą pokrywać z własnych środków ${ }^{54}$. W przepisach Regulaminu zalecano, aby kapłani angażowali się w pracę duszpasterską, pamiętając jednak, że ich dodatkowe zajęcia nie mogą przesłaniać najważniejszego celu pobytu w Kolegium, czyli formacji intelektualnej i duchowej ${ }^{55}$. Określono precyzyjnie, że Kolegium jest otwarte dla księży studentów od 1 września do 30 czerwca i jednocześnie upoważniono rektora, aby w nagłych i wyjątkowych przypadkach mógł zezwolić na ich pobyt w okresie wakacyjnym ${ }^{56}$.

W punktach Regulaminu od ósmego do czternastego, opatrzonych odrębnym tytułem: ,Zasady życia”, powtórzono normy zawarte w Statucie, które dotyczą warunków przyjęcia studentów do Kolegium. Ponownie zwrócono uwagę na właściwe wykorzystanie czasu przez księży oraz na stałą, własną formację w duchu magisterium Kościoła ${ }^{57}$. Pobyt we wspólnocie Kolegium ma pomóc studentom nie tylko w zdobywaniu wiedzy na studiach specjalistycznych, ale także w poznawaniu Kościoła uniwersalnego i jego bogatej historii. Oto jak opisano te kwestie w punkcie 14.1 Regulaminu: „Oprócz możliwości uczęszczania na uniwersytety i instytuty papieskie, księża studenci znajdują tu sposobność poznania i przeżycia szczególnej bliskości Kościoła Rzymu oraz jego złożonej tradycji historycznej, kulturalnej i patriotycznej"58.

${ }^{54}$ Tamże.

${ }^{55}$ Por. pkt 6, tamże, s. 10.

${ }^{56}$ Pkt 7.2, tamże.

${ }^{57}$ Por. pkt 8, 9. Papieskie Kolegium Polskie w Rzymie. Statut z Regulaminem. Warszawa, 28-06-2002. APKP, sygn. III 28.5, s. 11. Część „Zasady życia” pominięto w Regulaminie Papieskiego Kościelnego Instytutu Polskiego w Rzymie. Dokument kończy się na punkcie siódmym, a treść jego jest bardzo podobna do Regulaminu Kolegium. Można stwierdzić, że przy tworzeniu Regulaminu Instytutu z pewnością korzystano ze sformułowanego wcześniej Regulaminu Kolegium. Por. Papieski Kościelny Instytut Polski w Rzymie. Regulamin. Warszawa, 30-01-2004. APKP, sygn. III 28.6.

${ }^{58}$ Por. pkt 8, 9, Papieskie Kolegium Polskie w Rzymie. Statut z Regulaminem. Warszawa, 28-06-2002. APKP, sygn. III 28.5, s. 11. 
W celu rozwoju życia wspólnotowego i dobrej organizacji pobytu, księża studenci wybierają spośród siebie raz w roku tzw. seniora, który reprezentuje ich wobec personelu Kolegium. Regulamin przewiduje też możliwość utworzenia funkcji studenckich, takich jak np.: wicesenior, bibliotekarz, zakrystianin, organista i dyrygent, jak i komisji studenckich (np. do spraw kultury, wypoczynku, liturgii) ${ }^{59}$.

$\mathrm{Na}$ podstawie przeprowadzonej analizy porównawczej można stwierdzić, że w pracach nad Statutem i Regulaminem Kolegium z 2002 r. korzystano ze Statutu, Zasad Życia i Regulaminu Papieskiego Seminarium Lombardo św. Ambrożego i Karola w Rzymie z 1991 r. Wynika to jasno z porównania struktury i treści tych dokumentów ${ }^{60}$. Wydaje się też oczywistym, że Statut i Regulamin Papieskiego Kolegium Polskiego posłużył jako wzór do stworzenia Statutu Papieskiego Kościelnego Instytutu Polskiego w Rzymie z 2004 r. ${ }^{61}$

\section{Zakończenie}

Prace nad zmianą Statutu i Regulaminu Papieskiego Kolegium Polskiego w Rzymie trwały od początku 1972 r. Aktualnie obowiązujący Statut i Regulamin został zaaprobowany przez Kongregację do spraw Wychowania Katolickiego dopiero w połowie 2002 r.

Obecnie Papieskie Kolegium Polskie jest rzymską instytucję kościelną, która pozostaje w szczególnej zależności od Stolicy Apostolskiej i jednocześnie jest poddana władzy oraz nadzorowi Konferencji Episkopatu Polski. Do Kolegium są przyjmowani księża z Polski, którzy po ukończeniu nauki i formacji w seminariach duchownych zostali skierowani przez swych biskupów do odbycia studiów specjalistycznych w kościelnych uczelniach rzymskich. Papieskie Kolegium Polskie jest instytucją posiadającą osobowość prawną w świetle prawa ka-

${ }^{59}$ Pkt 2.5, 2.6, tamże, s. 6.

${ }^{60}$ Por. Pontificio Seminario Lombardo dei santi Ambrogio e Carlo in Roma. Satuto Lineamenti di Vita e Regolamento, Roma 1991. APKP, sygn. III 44, s. 1-39.

${ }^{61}$ Por. Papieski Kościelny Instytut Polski w Rzymie. Regulamin. Warszawa, 30-012004. APKP, sygn. III 28.6. 
nonicznego, a w systemie prawa włoskiego osobowość prawną uznaną przez Republikę Włoską.

W Statucie Kolegium z 2001 r. podkreśla się, że wskazania dotyczące życia i zarządu tej instytucji są określone przez Konferencję Episkopatu Polski, z uwzględnieniem zarządzeń Kongregacji do spraw Wychowania Katolickiego odnoszących się do rzymskich kolegiów kościelnych. W porównaniu z poprzednim Statutem, w Kolegium zlikwidowano funkcję kardynała protektora i, w miejsce dwóch tzw. „deputatów”, utworzono Komisję Nadzorczą, składającą się z czterech polskich kapłanów rezydujących w Rzymie, mianowanych przez Konferencję Episkopatu Polski na okres pięciu lat, z możliwością ponowienia nominacji. Komisja ta ma zadania doradcze i czuwa nad przestrzeganiem zarządzeń Stolicy Apostolskiej i Konferencji Episkopatu Polski.

Prawnym reprezentantem Kolegium jest rektor, którego mianuje na sześcioletnią kadencję Kongregacja do spraw Wychowania Katolickiego, po uprzednim przedstawieniu kandydata przez Konferencję Episkopatu Polski. Rektor zobowiązany jest troszczyć się o właściwy przebieg życia w Kolegium, zgodnie ze wskazaniami Stolicy Apostolskiej oraz Konferencji Episkopatu Polski. W każdym roku zobowiązany jest przedkładać Kongregacji do spraw Wychowania Katolickiego i Konferencji Episkopatu Polski sprawozdanie o stanie Kolegium, ze szczególnym uwzględnieniem procesu formacyjnego studentów i sytuacji finansowej oraz majątkowej. Zgodnie $\mathrm{z}$ aktualnymi potrzebami Kolegium, Konferencja Episkopatu Polski może mianować wicerektora-ekonoma, kierownika duchownego, spowiedników zwyczajnych i nadzwyczajnych. Miejsce w Kolegium przyznaje studentom przewodniczący Konferencji Episkopatu Polski na wniosek zainteresowanego biskupa. W Statucie i Regulaminie Kolegium podkreślono znaczenie formacji duchowej i intelektualnej księży studentów.

W pracach nad nowym Statutem i Regulaminem Papieskiego Kolegium Polskiego korzystano ze Statutu, Zasad Życia i Regulaminu Papieskiego Seminarium Lombardo św. Ambrożego i Karola w Rzymie z 1991 r., a jak wynika z porównania struktury i treści dokumentów, 
Statut i Regulamin Kolegium posłużył za wzór do stworzenia Statutu Papieskiego Kościelnego Instytutu Polskiego w Rzymie.

\section{Statutes and Regulations of the Polish Pontifical College in Rome in $\mathbf{2 0 0 2}$}

The Polish Pontifical College in Rome is an institution of the church, which remains particularly dependent on the Holy See and at the same time, is subject to the authority and supervision of the Polish Episcopal Conference. Polish priests are admitted to the College after the completion of their studies and spiritual formation at the seminary. They are then directed by their bishop to pursue specialized studies at Roman ecclesiastical universities.

The Polish Pontifical College is an institution with legal personality, under Canon Law. This legal personality is also recognized within the Italian legal system by the Italian Republic. The College's rector is the legal representative. The Statutes and the Rules of the College emphasize the importance of spiritual and intellectual formation of student priests.

The 1991, Principles of Life and Rules of the Papal Seminary Lombardo, Saint Ambrosio and St. Charles of Rome were used in developing the new Statutes and the Rules of the Polish Pontifical College. 